\title{
Consolidation, Concentration, And Valuation In The Banking Industry
}

Yvette M. Bendeck, University of Houston-Clear Lake, USA

Edward R. Waller, University of Houston-Clear Lake, USA

\begin{abstract}
We assess whether gains in wealth associated with bank consolidation are the result of reduced competition by examining effects of merger announcements on values of bidders, targets and rivals. The results suggest that gains in wealth are not due to increases in market power at the level of individual banks. Specifically, we find that returns to bidders, targets and rivals are unrelated to the effects of mergers on concentration.
\end{abstract}

Keywords: bank mergers; concentration; value

\section{INTRODUCTION}

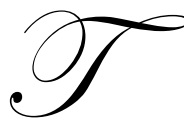

he United States placed significant restrictions on commercial banks for many decades. As a result, the U.S. banking system was less concentrated than the banking systems of many countries. Although U.S. legislation and regulation sought to encourage competition, Peltzman (1965) argued that the American regulatory structure preserved and strengthened pricing power in the banking industry. Consistent with this view, Cosimano and McDonald (1998), Neumark and Sharpe (1992), and Hannan and Berger (1991) reported that the behavior of deposit rates suggested pricing power at the level of individual banks. Since the late 1980s, however, notable relaxation of restrictions on commercial banks and waves of bank mergers have reduced the number of banks in the U.S. from more then 14,000 in the early 1980s to less than 6,500 in the fourth quarter of 2010. Moreover, almost all bank mergers were intrastate consolidations prior to 1985 , but a more liberal attitude by legislators and regulators led to a considerable number of both interstate and intrastate mergers in the past three decades.

Previous studies of bank acquisitions, such as Bendeck and Waller (2007), Rosen (2006), DeLong (2001), Houston et al. (2001), Becher (2000), Akhigbe and Madura (1999), Houston and Ryngaert (1994), Cornett and Tehranian (1992), Cornett and De (1991), and James and Wier (1987), use stock market data to document that bank mergers generate large gains in wealth for shareholders of target banks. The benefits of acquisitions for acquiring banks are less clear, given the ambiguous pattern of share-price effects. DeLong and DeYoung (2007) suggest that academic studies reject the hypothesis that bank acquisitions create value because investors are unable to accurately assess the value of bank acquisitions when regulations, technologies, industry structure, and merger profiles are changing rapidly. DeLong (2001) also shows bank mergers that enhance value at announcement can be distinguished from those mergers that do not by classifying mergers according to activity and similarity and then examining the abnormal returns to each group as a result of merger announcement.

Results in previous studies are ambiguous about the subsequent operating performance of merged banks. Moreover, little evidence about the effects of increased consolidation on competition in banking exists. Specifically, empirical cost analyses of bank consolidations have historically suggested that economies of scale are weak and average costs are flat. For example, Srinivasan (1992) reported that declines in operating costs for merged banks parallel those of the banking industry, while Berger and Humphrey (1992) and Cornett and Tehranian (1992) report evidence of post-merger cost efficiencies. Hunter and Timme (1989) found no evidence for economies of scope in banking and Gorton and Rosen (1995) indicated that mergers do not reduce excess lending capacity. In a review of the bank merger and cost efficiency literature, Berger et al. (1999) report little or no cost efficiency improvement from bank consolidations. 
In this paper, we analyze the concentration effects of bank mergers on market values of bidders, targets and rivals. Like DeLong (2001), we define rivals as banks located in the same geographical area as the target bank. This approach allows us to evaluate the information effects of bank mergers and to gain perspective on the sources of economic gains or losses associated with consolidation. We focus on differences between acquisitions that involve banks with overlapping markets versus consolidations between banks operating in markets that do not overlap, an assessment of the impact of each type of event on rivals, and an analysis of whether stock price returns at announcement are affected by the change in concentration.

This paper provides evidence that differentiates between three hypotheses about motivations for bank mergers. First, the concentration hypothesis suggests bank mergers increase concentration and generate profits at the expense of customers. This hypothesis assumes there are significant barriers to entry that may result in market power. If competition is expected to decline as a result of consolidation, then parties to a consolidation, as well as rivals, may be more profitable. Moreover, larger increases in wealth may result from higher concentration. Of course, if banking and deposit markets are contestable at the level of individual banks, changes in concentration induced by merger will not affect values. Second, the efficiency hypothesis predicts that a control transaction transfers assets from target banks to acquiring banks that can more efficiently utilize and manage target assets. From this perspective, bank mergers permit bidders to seize economies of scale and scope. Mergers that generate synergies strengthen the efficiency and competitiveness of consolidating banks who gain at the expense of rivals. Third, the information hypothesis suggests well-informed acquirers with positive private information about a target bank are prepared to pay more for a target than the value currently perceived by the market. Control activity conveys credible evidence of this mispricing to the market, enhancing the value of the target. If some of this information applies to banks in the same market, rivals will also gain in value. This information-based gain in value should not be affected by the degree to which market concentration increases as a result of consolidation.

The relevance of these hypotheses is tested by examining share-price responses to acquisition announcements for target banks, bidding banks and rivals of target banks, and by disaggregating the results based on whether the merger has an effect on concentration. We also assess the effect of changes in concentration on gains in wealth from bank merger announcements by using regressions in which returns are specified as a function of the change in market concentration induced by merger, as well as other potential determinants of changes in value.

We find there are positive and equivalent excess returns to targets in mergers in which the target and bidder have overlapping markets and in mergers between banks without overlapping markets. For bidding banks, excess returns at merger announcements are negative and statistically significant only for transactions in which bidders and targets have overlapping markets. Thus, returns to bidders in mergers that increase concentration are more unfavorable than returns to bidders in mergers that leave concentration unaltered. Returns to rivals are significantly greater in bids by acquirers whose operations do not overlap the target's markets than in acquisitions in which bidder and target markets overlap. In addition, cross-sectional regressions indicate that returns to bidders, targets, and rivals are not affected by change in concentration resulting from consolidation. Overall, the results are not consistent with the hypothesis that concentration is a source of wealth gains in mergers and acquisitions in the banking industry.

The remainder of this paper is organized as follows. We discuss data and methodology in the following section. Then, we report our empirical evidence. We conclude with a summary and discussion of implications.

\section{METHODOLOGY}

The sample of bank acquisitions is obtained from several sources, including Mergers and Acquisitions, the Federal Reserve Bulletin, and the American Banker. The sample consists of acquisitions involving publicly traded bank holding companies so that each merger requires the approval of the Federal Reserve Board before the consolidation can be consummated. We also obtain information about the identity of other publicly traded rival banks that operate in a deposit market of the target bank. The two major criteria for retention of a merger in the sample are that one, the target and/or bidder and rival banks must have sufficient daily stock price data on the Center for Research in Securities Prices (CRSP) NYSE, AMEX or NASDAQ files to allow estimation of an event study model and, two, the relevant Federal Reserve staff report on the merger must be available. We exclude acquisitions 
in which there are multiple bidders since share price responses for targets, bidders and rivals in response to announcements of such events can be expected to reflect expectations about the probability that a bidding contest will develop, the impact of activities conducted by competing bidders, and the anticipated effects of the original acquisition bid. Regulatory sales and auctions of failed banks are also excluded.

Information about the samples of banks and transaction characteristics are collected from Wall Street Journal articles, Mergent Online, and the American Banker. This data allows us to disaggregate the sample into events in which the target and the bidder have overlapping deposit markets versus events in which the bidder and target do not have overlapping markets. In addition, we are able to identify whether the target bank was in financial distress at the time of the acquisition bid.

Excess returns are calculated using the market model over a 120 day period, days -250 to -131 , prior to each announcement, day 0 . We report cumulative excess returns during two-day and five-day announcement windows for target and bidding banks. In the case of rival banks, for each event we average excess returns for all relevant rivals, then we average the pooled returns over all events each day and cumulate these returns over the relevant announcement window. This procedure for generating rival excess returns follows the procedure used in Bendeck and Waller (2007), Lang and Stulz (1992) and Slovin et al. (1991). The null hypothesis of the statistical test is that the average excess return equals zero. The test statistic, reported in parentheses in the tables below the relevant return, is the ratio of the relevant average excess return to its estimated standard deviation obtained from the time series of excess returns during the 120 day pre-event estimation period (-250 to -131).

\section{MARKET REACTION TO ACQUISITION ANNOUNCEMENTS FOR TARGET BANKS}

Bendeck and Waller (2007) suggest the market anticipates bank acquisition announcements for target banks, but this anticipation is only partial since the actual announcement generates a large positive effect on target bank share price. They also report a small, but not statistically significant, return for the post-announcement period. In this paper, we disaggregate the sample into 32 cases in which there is no overlap between the deposit markets of bidder and target banks versus 63 cases where the merging banks have overlapping markets. As reported in Panel A of Table 1, the two-day excess return to target banks is $10.75 \%$ with a t-statistic of 22.83 for the sample of no overlap events. For the sample of events with overlapping markets, the two-day excess return to targets is $12.41 \%$ with a t-statistic of 30.87. Although the two-day excess return for the overlap group is higher than for the no overlap group, the magnitude of the difference is small. A difference in means test between the valuation effects for the two samples of banks generates a calculated $t$-value of 0.87 , which is not significant at the $5 \%$ level. Moreover, the fiveday share-price reactions for the two samples are almost identical. Thus, we cannot reject the null hypothesis of equality and conclude announcements of bank acquisitions generate similar share-price reactions for target banks regardless of whether the bidder bank operates in the target's market prior to the bid.

\section{MARKET REACTION TO ACQUISITION ANNOUNCEMENTS FOR ACQUIRING BANKS}

Bendeck and Waller (2007) also report negative returns to acquirers in response to acquisition announcements and suggest the market does not anticipate the identity of bidding banks prior to announcement. The excess returns to bank acquirers are consistent with the negative and significant returns for acquirers of financial firms reported by DeLong (2001) (-1.68\%) and for acquirers of nonfinancial firms reported by Byrd and Hickman (1992) (-1.20\%), Bradley, Desai and Kim (1988) (-2.90\%), Servaes (1991) (-3.3\%), Varaiya and Ferris (1987) ($2.15 \%)$, and Jennings and Mazzeo (1991) (-0.80\%), and may be suggestive of overbidding.

We disaggregate the sample into 52 cases where there is no overlap of bidder and target deposit markets versus 101 cases where there are overlapping markets. As reported in Panel B of Table 1, the two-day excess return for bidding banks where there is no overlap is $-0.35 \%$ with a t-statistic of -1.14 , which is not statistically significant. For cases in which there is an overlap of deposit markets, the two-day excess return to bidder banks is $-1.76 \%$ with a t-statistic of -9.43 , significant at the $1 \%$ confidence level. A difference in means test generates a calculated t-value of 2.87 , significant at the $1 \%$ confidence level. Thus, the two-day excess return to bidders in markets that overlap target markets is significantly more unfavorable than for bidders that do not have overlapping markets. The five-day share-price reactions for these two samples of bidding banks resemble the pattern of two-day returns. 
Table 1: Excess Returns by Market Competition Status

Average prediction errors ${ }^{\mathrm{a}}$ in percentage terms for banks that are targets of acquisition bids, bidders in acquisition bids, and rivals of banks that are targets of acquisition bids disaggregated by whether the merging banks operate in overlapping markets, and are traded on the New York or American Stock Exchange or NASDAQ; (t-statistics in parentheses ${ }^{\mathrm{b}}$, proportion of positive returns in brackets).

\begin{tabular}{|c|c|c|c|}
\hline & $\begin{array}{c}\text { Two-day return } \\
(-1,0)\end{array}$ & $\begin{array}{c}\text { Five-day return } \\
(-4,0)\end{array}$ & $\begin{array}{c}\text { Pre-event period return } \\
(-15,-2)\end{array}$ \\
\hline \multicolumn{4}{|c|}{ Panel A: For Target Banks } \\
\hline $\begin{array}{l}\text { No overlap } \\
\mathrm{N}=32\end{array}$ & $\begin{array}{c}10.75 \\
(22.83) * * \\
{[0.73]}\end{array}$ & $\begin{array}{c}10.64 \\
(14.29)^{* *}\end{array}$ & $\begin{array}{c}6.69 \\
(5.37)^{* *}\end{array}$ \\
\hline $\begin{array}{l}\text { Overlap } \\
\mathrm{N}=63\end{array}$ & $\begin{array}{c}12.41 \\
(30.87)^{* *} \\
{[0.78]}\end{array}$ & $\begin{array}{c}11.73 \\
(18.45)^{* *}\end{array}$ & $\begin{array}{c}6.30 \\
(5.88)^{* *}\end{array}$ \\
\hline \multicolumn{4}{|c|}{ Panel B: For Bidder Banks } \\
\hline $\begin{array}{l}\text { No overlap } \\
\mathrm{N}=52\end{array}$ & $\begin{array}{c}-0.35 \\
(-1.14) \\
{[0.50]}\end{array}$ & $\begin{array}{l}-0.12 \\
(-0.26)\end{array}$ & $\begin{array}{c}0.32 \\
(0.40)\end{array}$ \\
\hline $\begin{array}{l}\text { Overlap } \\
N=101\end{array}$ & $\begin{array}{c}-1.76 \\
(-9.43)^{* *} \\
{[0.27]}\end{array}$ & $\begin{array}{c}-1.02 \\
(-3.48)^{* *}\end{array}$ & $\begin{array}{c}0.69 \\
(1.40)\end{array}$ \\
\hline \multicolumn{4}{|c|}{ Panel C: For Rival Banks } \\
\hline $\begin{array}{l}\text { No overlap } \\
\mathrm{N}=50\end{array}$ & $\begin{array}{c}1.97 \\
(7.80)^{* *} \\
{[0.60]}\end{array}$ & $\begin{array}{c}1.85 \\
(4.63)^{* *}\end{array}$ & $\begin{array}{c}-69 \\
(-1.03)\end{array}$ \\
\hline $\begin{array}{l}\text { Overlap } \\
\mathrm{N}=98\end{array}$ & $\begin{array}{c}0.59 \\
(4.07)^{* *} \\
{[0.51]}\end{array}$ & $\begin{array}{c}0.52 \\
(2.25)^{*}\end{array}$ & $\begin{array}{c}0.05 \\
(0.11)\end{array}$ \\
\hline
\end{tabular}

a Prediction errors are calculated as the difference between realized returns and expected returns obtained from a least squares regression estimated over the pre-event period -250 to -131 , where day $\mathrm{t}=0$ is the date of first announcement. Rival banks are grouped into portfolios by event as described in the Methodology section.

b Statistical significance is indicated by:

*Significant at the $5 \%$ confidence level

**Significant at the $1 \%$ confidence level

Thus, announcements of bank acquisitions generate negative share price effects for bidders that are statistically significant only when the bidding bank's deposit markets overlap those of the target.

\section{MARKET REACTION TO ACQUISITION ANNOUNCEMENTS FOR RIVAL BANKS}

Bendeck and Waller (2007) report that merger announcements generate significantly positive effects on the share prices of rival banks. Positive returns to rivals at bank merger announcements can result from expectations of lessened competition or from positive information conveyed about the valuation of target bank assets. To gain additional insight on this question, we disaggregate the sample of rival banks on the basis of whether the bidder and the target banks operate in overlapping deposit markets prior to the merger announcement. If the bidder and target banks have overlapping deposit markets and the financial market expects bank consolidations to generate gains due to reduced deposit rates, increased fees, or reductions in service quality, then rival banks should also benefit and rival bank share prices should increase in response to the merger announcement. If the bidder and target do not have overlapping deposit markets, the merger has no effect on market concentration and rival bank share prices should be unaffected. Thus, if the concentration hypothesis is valid, positive effects on rival banks should be limited to mergers in which the bidder and target have overlapping markets. In comparison, if merger announcements reveal positive private information that the acquirer possesses about the target bank and if elements of this information apply to other banks operating in the same area as the target, then merger announcements should generate positive 
valuation effects for rival banks regardless of whether the acquirer has operations in the target banks' markets. Positive returns to rival banks could reflect expectations of higher future cash flows for rivals after the merger or expectations that other banks in the area are likely to become targets of future control bids.

When the intra-industry effects of bank acquisitions are disaggregated based on whether the target and bidder banks have overlapping deposit markets, there are positive and statistically significant excess returns for both samples of rival banks. The returns are more favorable when the bidder and target banks do not have overlapping markets. Specifically, the returns to rival banks are 1.97\% (t-statistic of 7.80) for the no overlap sample and $0.59 \%$ (t-statistic of 4.07) for the overlapping markets sample, as reported in Panel C of Table 1. A difference in means test between these two returns generates a calculated t-value of 2.23 , which is statistically significant at the $5 \%$ level. The five-day share-price reactions for rival banks in these two samples are almost identical to the two-day returns. These results are consistent with the view that positive gains to rival banks reflect positive private information conveyed by bids about target bank values and that this information is viewed by market participants as having geographically common elements. Since merger bids entail the expenditure of considerable resources by bidders in researching potential acquisition targets, the results suggest shareholders of rivals obtain significant benefits from the information gathering activities of bidders.

\section{CROSS-SECTIONAL REGRESSION ANALYSIS}

We also use cross-sectional regressions to assess factors that influence returns to bidders, targets, and rivals of targets in response to bank merger announcements. The dependent variables are two-day excess returns to targets, acquirers and rivals. Independent variables reflect characteristics of the transactions and participating banks. The results are reported in Table 2. T-statistics are reported in parentheses.

Since Bendeck and Waller (2007) suggest the presence of financial distress at target banks is an important determinant of rival returns, we include a qualitative variable, DISTRESS, that equals one when a target bank is in distress and zero otherwise. Since Asquith, Bruner, and Mullins (1983) and Travlos (1987) report the use of equity financing has adverse effects on bidder returns, we include a qualitative variable, STOCK, that equals one when equity is included in the means of payment and zero otherwise.

We use Herfindahl-Hirschman concentration index variables (HHI) to measure the effect of market concentration on bank returns. Specifically, we include three variables, $\Delta \mathrm{HHI}(1), \Delta \mathrm{HHI}(2)$, and $\Delta \mathrm{HHI}(3)$, to measure the change in the HHI induced by merger in the target bank's primary, secondary, and tertiary markets. If the bidder and target have no overlapping operations, then all three variables are zero. The data on concentration are obtained from reports prepared by Federal Reserve staff. These reports are submitted to the Federal Reserve Board prior to its vote on a merger. We also include a qualitative variable, DOJ, that equals unity when a merger violates Department of Justice concentration guidelines, and zero otherwise; and the qualitative variable, DIVEST, that equals unity when the merging banks divest certain affiliated banks, branches, and/or deposits to gain regulatory approval for the transaction, and zero otherwise. Finally, we include the qualitative variable, INTERSTATE, that equals unity for an interstate merger and zero otherwise.

The pattern of coefficients suggests three results. First, consistent with the event study evidence reported by Bendeck and Waller (2007), target bank distress has a positive and significant effect on returns to rival banks. Distress does not affect the returns to bidders or targets. Second, as in the case of nonfinancial mergers and acquisitions, the use of equity as the means of payment in a bank merger is a negative signal about acquiring bank value. This suggests the prevalence of stock as the means of payment in bank mergers is an important element in explaining the presence of negative returns to bank bidders. Third, variables that relate to concentration or market power do not influence returns to targets, bidders, or rivals. None of the coefficients of variables that reflect the change in concentration induced by bank merger are statistically significant. There is also no evidence that bank mergers that violate Department of Justice guidelines and/or require the divestiture of certain operations for regulatory approval generate greater gains in wealth. Moreover, there is no evidence to support the hypothesis that interstate mergers have different wealth effects than intrastate mergers. Based upon these results and the poor level of explanatory power associated with variables that reflect competition, we conclude that gains generated by bank mergers are not the result of increased concentration. 
Table 2: Cross-sectional Regressions for Target, Bidder, and Rival Bank Excess Returns

Cross-sectional regressions are estimated to explain the two-day $(-1,0)$ cumulative average prediction errors from the event studies for the full sample of targets, bidders, and rivals at merger announcements; t-statistics are in parentheses. ${ }^{\text {a }}$

\begin{tabular}{|c|c|c|c|}
\hline Explanatory variables $^{b}$ & Targets & Acquirers & Rivals \\
\hline DISTRESS & $\begin{array}{c}-0.0419 \\
(-0.91)\end{array}$ & $\begin{array}{c}-0.0128 \\
(-1.15)\end{array}$ & $\begin{array}{c}0.0182 \\
(3.95)^{* *}\end{array}$ \\
\hline STOCK & $\begin{array}{c}-0.0124 \\
(-0.40)\end{array}$ & $\begin{array}{l}-0.0158 \\
(-1.98)^{*}\end{array}$ & $\begin{array}{c}0.0054 \\
(1.41)\end{array}$ \\
\hline$\Delta \mathrm{HHI}(1)$ & $\begin{array}{c}-0.0002 \\
(-0.82)\end{array}$ & $\begin{array}{c}0.0001 \\
(1.42)\end{array}$ & $\begin{array}{c}0.0000 \\
(0.56)\end{array}$ \\
\hline$\Delta \mathrm{HHI}(2)$ & $\begin{array}{c}0.0001 \\
(0.31)\end{array}$ & $\begin{array}{c}-0.0000 \\
(-0.48)\end{array}$ & $\begin{array}{c}0.0000 \\
(0.60)\end{array}$ \\
\hline$\Delta \mathrm{HHI}(3)$ & $\begin{array}{c}0.0001 \\
(0.18)\end{array}$ & $\begin{array}{c}-0.0000 \\
(-1.03)\end{array}$ & $\begin{array}{c}0.0001 \\
(1.55)\end{array}$ \\
\hline DOJ & $\begin{array}{c}0.0845 \\
(1.02)\end{array}$ & $\begin{array}{c}-0.0184 \\
(-0.98)\end{array}$ & $\begin{array}{c}0.0006 \\
(0.06)\end{array}$ \\
\hline DIVEST & $\begin{array}{c}0.0565 \\
(1.38)\end{array}$ & $\begin{array}{c}00.0014 \\
(0.13)\end{array}$ & $\begin{array}{c}-0.0040 \\
(-0.96)\end{array}$ \\
\hline INTERSTATE & $\begin{array}{c}-0.0314 \\
(-0.69)\end{array}$ & $\begin{array}{c}0.0041 \\
(0.40)\end{array}$ & $\begin{array}{c}0.0101 \\
(1.62)\end{array}$ \\
\hline Intercept & $\begin{array}{c}0.1466 \\
(1.47)\end{array}$ & $\begin{array}{c}-0.0002 \\
(-0.01)\end{array}$ & $\begin{array}{c}0.0113 \\
(1.15)\end{array}$ \\
\hline $\mathrm{R}^{2}$ & 0.0227 & 0.1168 & 0.0766 \\
\hline $\mathrm{F}$ & 1.15 & $2.03 *$ & $5.53 * *$ \\
\hline
\end{tabular}

${ }^{a}$ Statistical significance indicated by $*$ significant at the $5 \%$ level; $* *$ significant at the $1 \%$ level.

${ }^{b}$ The independent variables are defined as:

DISTRESS is a qualitative variable that equals one when a target bank is in distress, and zero otherwise.

STOCK is a qualitative variable that equals one when equity is the means of payment, and zero otherwise.

$\triangle H H I(i)$ is the change in the Herfindahl-Hirschman concentration index for the ith market.

DOJ is a qualitative variable that equals one when a merger violates the antitrust standards of the Department of Justice, and zero otherwise.

DIVEST is a qualitative variable that equals one when divestiture of assets is required for merger approval, and zero otherwise.

INTERSTATE is a qualitative variable that equals one when a merger is interstate, and zero otherwise.

\section{CONCLUSIONS}

This paper provides evidence about the share price effects of bank mergers and analyzes whether wealth gains in response to these consolidations reflect increases in concentration at the level of individual banks. Although we find target banks earn large positive excess returns, announcements of bank acquisitions generate similar share-price reactions for target banks regardless of whether bidders operate in target markets prior to bids. Announcements of bank acquisitions generate negative share price effects for bidders that are statistically significant only when the bidding bank's deposit markets overlap those of the target bank. Rival banks earn positive returns in response to bank acquisition announcements, but there is no evidence that this is due to expectations of lessened competition as a result of bank consolidation. Indeed, rival returns are less positive for the sample of mergers among banks with overlapping deposit markets than for mergers between banks without overlapping markets. Moreover, positive rival returns in response to merger announcement are not consistent with the hypothesis that relevant event- 
specific or bank-specific characteristics may reflect increased efficiencies that, in turn, are favorably reflected in market prices.

The results have interesting implications for regulatory policy. Since regulators have responsibility for enforcing antitrust statutes, as well as authority to evaluate competitive effects in determining whether to approve a merger, regulatory guidelines incorporate changes in market concentration, assessments about competitive conditions, existence of barriers to entry, and whether a merger may generate efficiency gains that would benefit customers. Our results suggest that gains in wealth from bank mergers are not the result of increased concentration or efficiencies, but rather reflect positive, specific information that may be affected by event-specific or bankspecific characteristics.

\section{AUTHOR INFORMATION}

Yvette M. Bendeck is Associate Vice President of Enrollment Management and Professor of Finance at the University of Houston-Clear Lake. E-mail: bendeck@uhcl.edu

Edward Waller is Interim Associate Dean and Professor of Finance in the School of Business at the University of Houston-Clear Lake. E-mail: waller@uhcl.edu

\section{REFERENCES}

1. Akhigbe, A., and J. Madura, 1999. Intra-industry signals embedded in bank acquisition announcements. Journal of Banking and Finance 23: 1637-1654.

2. $\quad$ Becher, D., 2000. The valuation effects of bank mergers. Journal of Corporate Finance 6: 189-214.

3. Bendeck, Y., and E. Waller, 2007. Bank acquisition announcements and intra-industry effects. Journal of Business and Economics Research 5: 15-21.

4. Berger, A., and D. Humphrey, 1992. Mega-mergers in banking and the use of cost efficiency as an antitrust defense. The Antitrust Bulletin 33.

5. Berger, A., R. Demsetz, and P. Strahan, 1999. The consolidation of the financial services industry: Causes, consequences, and implications for the future. Journal of Banking and Finance 23: 135-194.

6. Bradley, M., A. Desai, and E. Kim, 1988. Synergistic gains from corporate acquisitions and their division between the stockholders of target and acquiring firms. Journal of Financial Economics 21: 3-40.

7. Byrd, J., and K. Hickman, 1992. Do outside directors monitor managers? Evidence form tender offers. Journal of Financial Economics 32: 195-222.

8. Cornett, M., and S. De, 1991. Common stock returns in corporate takeover bids: Evidence from interstate bank mergers. Journal of Banking and Finance 15: 273-295.

9. Cornett, M., and H. Tehranian, 1992. Changes in corporate performance associated with bank acquisitions. Journal of Financial Economics 31: 211-234.

10. Cosimano, T., and B. McDonald. 1998. What's different among banks? Journal of Monetary Economics 41: 57-70.

11. DeLong, G., 2001. Stockholder gains from focusing versus diversifying bank mergers. Journal of Financial Economics 59: 221-252.

12. DeLong, G., and R. DeYoung, 2007. Learning by observing: Information spillovers in the execution and valuation of commercial bank M\&As. Journal of Finance 62: 181-216.

13. Gorton, G., and R. Rosen, 1995. Corporate control, portfolio choice, and the decline of banking. Journal of Finance 50: 1377-1420.

14. Hannan, T., and A. Berger, 1991, The rigidity of prices: Evidence from the banking industry. American Economic Review 81: 938-945.

15. Houston, J., and M. Ryngaert, 1994. The overall gains from large bank mergers. Journal of Banking and Finance 18: 1155-1176.

16. Houston, J., C. James, and M. Ryngaert, 2001. Where do merger gains come from? Bank mergers from the perspective of insiders and outsiders. Journal of Financial Economics 60: 285-331.

17. Hunter, W., and S. Timme, 1989. Does multi-product production in large banks reduce costs? Federal Reserve Bank of Atlanta Business Review: 2-11. 
18. James, C., and P. Wier, 1987. An analysis of FDIC failed bank auctions. Journal of Monetary Economics 20: 141-153.

19. Jennings, R., and M. Mazzeo, 1991. Stock price movements around acquisition announcements and management's response. Journal of Business 64: 139-164.

20. Lang, L., and R. Stulz, 1992. Contagion and competitive intra-industry effects of bankruptcy announcements. Journal of Financial Economics 32: 45-60.

21. Neumark, D., and S. Sharpe, 1992. Market structure and the nature of pure rigidity: Evidence from the market for consumer deposits. Quarterly Journal of Economics 107: 657-680.

22. Peltzman, S., 1965, Entry in commercial banking. Journal of Law and Economics 8: 11-50.

23. Rosen, R., 2006. Merger momentum and investor sentiment: The stock market reaction to merger announcements. Journal of Business 79: 987-1017.

24. Servaes, H., 1991. Tobin's Q and the gains from takeovers. Journal of Finance 46: 409-426.

25. Slovin, M., M. Sushka, and Y. Bendeck, 1991. The intra-industry effects of going private. Journal of Finance 46: 1537-1550.

26. Srinivasan, A., 1992. Are there cost savings from bank mergers? Federal Reserve Bank of Atlanta Economic Review: 17-28.

27. Varaiya, N., and K. Ferris, 1987. Overpaying in corporate takeovers: The winner's curse. Financial Analysts Journal 43: 64-71. 